\section{Multi-state models for defining degrees of chronicity related to HIV-infected patient therapy adherence}

\author{
Modelos multiestado para determinação dos \\ graus de cronicidade de acordo com a adesão \\ de paciente infectado pelo HIV
}

Modelos multi-estado para la determinación de los grados de cronicidad, de acuerdo con la adhesión del paciente infectado por el VIH

Raquel de Vasconcellos Carvalhaes de Oliveira ${ }^{1}$ Silvia Emiko Shimakura 2

Dayse Pereira Campos ${ }^{1}$

Flaviana Pavan Victoriano 1

Sayonara Rocha Ribeiro 1

Valdiléa G. Veloso 1

Beatriz Grinsztejn 1

Marilia Sá Carvalho ${ }^{3}$

\title{
Resumo
}

1 Instituto de Pesquisa Clínica Evandro Chagas, Fundação Oswaldo Cruz, Rio de Janeiro, Brasil.

2 Setor de Ciências Exatas, Universidade Federal do Paraná, Curitiba, Brasil. 3 Programa de Computação Científica, Fundação Oswaldo Cruz, Rio de Janeiro, Brasil.

Correspondence R. V. C. Oliveira

Laboratório de Epidemiologia Clínica, Instituto de Pesquisa

Clínica Evandro Chagas Fundação Oswaldo Cruz. Av. Brasil 4365, Rio de Janeiro, RJ 21040-360, Brasil. raquel.vasconcellos@ipec. fiocruz.br
Few studies on AIDS that evaluate factors associated with treatment failure have considered the slow evolution of the disease and multiple health state transitions following the use of antiretrovirals. In this article we study factors associated with the progression between different stages of the disease, focusing on therapy adherence using a sample of $722 \mathrm{HIV}+$ patients followed up for 3 years. States were defined using the following classifications of the CD4 cell count: $s_{1}(C D 4 \geq$ 500); $s_{2}(350 \leq C D 4<500) ;$ and $s_{3}(C D 4<350)$. The transitions between states were modeled using multi-state models. Antiretroviral therapy adherence and disease duration were associated with transitions between immune states during follow-up. Low adherence increased the hazard ratio of a transition between $s_{1}$ to $s_{2}$ and intermediate adherence increased the hazard ratio of a transition between $s_{2}$ to $s_{3}$. On the other hand, older age and disease duration between two and four years are protective factors for AIDS progression. Multi-state modeling is a powerful approach for studying chronic diseases and estimating factors associated with transitions between each stage of progression, thus enabling the use of more individualized and effective interventions.

HIV; Disease Progression; Patient Compliance; Survival Analysis
Poucos estudos sobre AIDS que avaliam fatores associados à falha terapêutica consideram sua evolução lenta, com a passagem por múltiplos estados de saúde, consequência do uso de antirretrovirais. Nesse artigo foram estudados fatores associados à progressão entre estados imunes, enfocando adesão, em 722 pacientes HIV+acompanhados por 3 anos. O desfecho foi a contagem de células CD4 classificada em $s_{1}(C D 4 \geq 500), s_{2}$ $(350 \leq C D 4<500)$ e $s_{3}(C D 4<350)$. As transições entre estados foram modeladas por modelos multiestado. A adesão à terapia antirretroviral e o tempo de doença estão associados diferentemente à mudança do estado imune vivido pelo paciente. Baixa adesão à terapia aumentou o risco de $s_{1} \rightarrow s_{2}$ e adesão intermediária aumentou o de $s_{2} \rightarrow s_{3}$. Por outro lado, idades elevadas e tempo de doença de 2 a 4 anos se apresentam como fatores de proteção na progressão da AIDS. A modelagem multiestado é uma abordagem poderosa no estudo de doenças crônicas, por estimar os fatores associados a cada etapa da evolução de doenças crônicas, possibilitando a adoção de intervenções mais individualizadas e eficazes.

HIV; Progressão da Doença; Cooperação do Paciente; Análise de Sobrevivência 


\section{Introduction}

Improvements in patient survival and quality of life were observed with the introduction of highly active anti-retroviral therapy (HAART) for the treatment of AIDS patients in the 1990s 1,2. One obstacle to successful therapy is the emergence of viral resistance, which is often associated with poor patient adherence to therapy. While the most significant challenge for effective therapy is undoubtedly to ensure patient compliance, there is no consensus on the minimum level of adherence needed to achieve viral suppression and adequate immune status 3 .

Few studies have assessed the influence of adherence to therapy on disease progression. Studies by Gross et al. ${ }^{4}$ in the United States and Campos 5 in Brazil have found that, in addition to adherence, age can be a cause of treatment failure. Gross et al. 4 also found that prior treatment and injected drug use can also affect treatment failure. In Brazil, Campos also found that 5 treatment failures are also associated with experience of previous AIDS-defining diseases and the average number of drugs administered per day.

Most studies of AIDS have analyzed the factors associated with therapeutic failure, such as death, opportunistic disease, detectable viral load (VL) or low levels of immunity, using semiparametric Cox models 4,6,7,8,9,10,11,12. However, it is also important to consider chronicity and the relatively slow progression of the disease and to assess the multiple immune states resulting from the effect of the virus on the human immune system.

The CD4 lymphocyte count, VL and onset of symptoms are commonly used indicators for monitoring the clinical progress of AIDS patients. Although the criteria used in Brazil for diagnosing AIDS are similar to international standards, the CD4 count cut-off point that defines the most severe condition is higher (CD4 < 350cells/ $\left.\mathrm{mm}^{3}\right)^{13}$. It is important to note that this classification has significant limitations partly due to the relatively arbitrary choice of cut-off point, measurement errors, the common occurrence of misclassifications, and also to the fact that HAART is available only to patients that show these cut-off points.

External factors, such as the use of immunosuppressive drugs, time of collection and the equipment used for flow cytometry, can influence the result of the CD4 count. Apart from the problems involved in using an immunological marker to define a medical condition, the classification of disease severity using CD4 count ranges in CD4 counts close to the cut-off point is open to error and may lead to misclassification 14.
The use of multi-state Markov models to analyze the factors associated with transitions between different states of chronicity has been suggested for chronic diseases and the cost-effectiveness of various therapeutic regimes 15,16,17,18,19,20. This approach allows individual patient analysis of factors that influence transitions between specific states 21 .

Some studies have applied multi-state models to analyze the transition between different states of AIDS severity, as defined by arbitrary CD4 counts and/or VL 22,23,24. Kousignian et al. 22 and Mathieu et al. 24 have evaluated misclassifications of approximate immunological and virological chronicity states according to the CD4 count and VL, and have assessed additional cutoff points to classify patient outcomes.

The aim of the present study was to analyze therapy adherence and socioeconomic and therapeutic factors that may affect the transition between different states of chronicity among AIDS patients receiving HAART and to evaluate immune status misclassifications.

\section{Methods}

\section{Population}

A cohort of $900 \mathrm{HIV}$-infected patients from the Evandro Chagas Institute of Clinical Research belonging to the Osvaldo Cruz Foundation (Instituto de Pesquisa Clínica Evandro Chagas, Fundação Oswaldo Cruz - IPEC/Fiocruz, acronym in Portuguese) in Rio de Janeiro, Brazil, receiving HAART between 2006 and 2008, was analyzed by this study. The study included patients who had been monitored for at least two years. Exclusion criteria included pregnancy and vertical transmission.

\section{Variables}

Data was extracted from medical records by trained health professionals (physicians and nurses) using a standardized form 25 .

The states of disease progression adopted in the multi-state model were defined based on of the following CD4 cell counts: $\geq 500$ cells/ $\mathrm{mm}^{3}\left(\mathrm{~s}_{1}\right) ; 350$ to 499 cells $/ \mathrm{mm}^{3}\left(\mathrm{~s}_{2}\right)$; and < 350cells / $\mathrm{mm}^{3}\left(\mathrm{~s}_{3}\right){ }^{13}$. The time lapse between state transitions was determined using the difference (in months) between the dates of CD4 tests. Due to the low mortality rates among the patients, it was not possible to use death as an absorbing state. With non-AIDS-related deaths $(n=23)$, the patient's state was therefore classified based on the last available CD4 count and the censored point 
was defined as the exact time of death. Where the patient's death was AIDS-related $(n=30)$, the lowest CD4 count was included in $s_{3}$ and time of death was defined as the previous day.

The demographic variables age (in years) at the first CD4 test and sex were analyzed. Due to the low number of cases of infection due to non-sexual exposure to the HIV virus (accident at work, injection by drug users and blood transfusion), patients were classified in just two exposure categories: sexual or non-sexual. Socioeconomic status was defined using the functional illiteracy criteria developed by United Nations Educational Scientific and Cultural Organization (UNESCO) and adapted for Brazil, according to which individuals with less than four years of schooling are considered functionally illiterate 26 .

Treatment was evaluated based on disease duration, specific combinations of anti-retroviral medicines, previous treatment and adherence to HAART. The latter aspect was measured using data from the Medication Logistics Control System 27 of the IPEC/Fiocruz pharmacy. The expected date for patient return to the pharmacy was calculated using the date of the last dispensation, the amount of the drug supplied and the dosage of each drug regime. The proportion of delay in return was calculated according to the difference between the expected return date and the observed date of return divided by the total number of days between two events (two states). The proportion of adherence was calculated as one minus the proportion of delay in return.

The treatment reference category was noneuse of HAART. The two other categories were the use of at least one protease inhibitor (PI) drug and the use of a non-nucleoside analogue reverse transcriptase inhibitor (NNRTI) drug. Additionally, we used an indicator variable to identify patients with a previous history of ARV treatment before the first CD4 test.

\section{Survival modelling}

The multi-state model evaluates the stages or states of progression of the disease and their transition probabilities using repeated measurements of individuals over time 28 .

The three states $\left(s_{1}, s_{2}\right.$ and $\left.s_{3}\right)$ were constructed using indirect measures of AIDS chronicity. Based on the assumption that the individual passed through the intermediate states to a more severe state, this process resulted in four permissible estimated transitions between adjacent states $\left(\mathrm{s}_{1} \rightarrow \mathrm{s}_{2}, \mathrm{~s}_{2} \rightarrow \mathrm{s}_{1}, \mathrm{~s}_{2} \rightarrow \mathrm{s}_{3}\right.$ and $\mathrm{s}_{3} \rightarrow \mathrm{s}_{2}$ ). In a Markov chain, the state transition depends solely on the current state 29,30,31. Multi-state
Markov models allow both the estimation of the hazard ratios (HR) of the covariates for each state change and the estimation of state misclassification, which makes it possible to estimate the probability of certain individuals having been observed in a certain state $i$ compared to the true state $j 32$.

Simple multi-state models for each explanatory variable were initially used to obtain the crude HR ratio. Splines were used to smooth the HRs of the two continuous variables (disease duration and adherence) with a non-linear behaviour. Based on the spline graph analysis for each transition, cut-off points were defined for the continuous variables. As expressing time intervals in years is more useful for clinical management, we approximated observed inflexions on the spline curve to disease durations of 12, 48 and 72 months (one, four and six years).

The explanatory variables were then sequentially modelled using multiple multi-state models in the following order: sociodemographic (e.g., gender, age, education and exposure category), care (e.g., disease duration, use of protease inhibitions and previous treatment) and interest (adherence to treatment). The likelihood-ratio test indicated the optimal multi-state model at the $5 \%$ significance level. Due to their theoretical relevance, gender, age, education and exposure category were maintained in the model, regardless of their statistical significance. Finally, the estimation of misclassifications of states of progression of the disease was included in the chosen model.

Goodness of fit was assessed according to the homogeneity of transition intensities and Pearson's residuals, which showed deviations in the values adjusted by the model, which in certain cases occurred across the most recent time periods (data not shown).

The analysis used the $m s m$ library 33 from the R software, version 2.13 (The R Foundation for Statistical Computing, Vienna, Austria; http:// www.r-project.org).

\section{Ethical issues}

Approval for this study was obtained from the IPEC/Fiocruz Ethics Research Committee.

\section{Results}

The study analyzed data obtained from 722 AIDS patients during two years of follow-up. Table 1 shows the distribution of the sociodemographic and anti-retroviral treatment variables at the beginning of patient follow-up and the observed 
Characteristics of 722 patients diagnosed with AIDS and receiving highly active anti-retroviral therapy (HAART). Instituto de Pesquisa Clínica Evandro Chagas, Fundação Oswaldo Cruz (IPEC/Fiocruz), Rio de Janeiro, Brazil, 2006-2008.

\begin{tabular}{|c|c|}
\hline Variables & \\
\hline Age (in years) in cohort admission [median (IR)] & $42.6(36.7-48.7)$ \\
\hline Disease duration (in months) at cohort admission [median (IR)] & $98.3(61.1-140.0)$ \\
\hline NADIR CD4 cell count at cohort admission [median (IR)] & $1148.5(59.5-242.8)$ \\
\hline Male $[n(\%)]$ & $454(62.9 \%)$ \\
\hline Married or consensual relationship [n (\%)] & $393(54.4 \%)$ \\
\hline \multicolumn{2}{|l|}{ Functional literacy [n (\%)] } \\
\hline More than 4 years of schooling & $168(23.3 \%)$ \\
\hline \multicolumn{2}{|l|}{ Ethnicity [n (\%)] } \\
\hline White & $430(59.6 \%)$ \\
\hline Brown & $206(28.5 \%)$ \\
\hline Black & $86(11.9 \%)$ \\
\hline \multicolumn{2}{|l|}{ Exposure to HIV [n (\%)] } \\
\hline Bisexual & $93(12.9 \%)$ \\
\hline Heterosexual & 409 (56.7\%) \\
\hline Homosexual & $175(24.2 \%)$ \\
\hline Blood transfusion & $27(3.7 \%)$ \\
\hline IDU & $18(2.5 \%)$ \\
\hline \multicolumn{2}{|l|}{ HAART at cohort admission [n (\%)] } \\
\hline $\mathrm{Pl}$ & $360(49.9 \%)$ \\
\hline NNRTI & $296(41.0 \%)$ \\
\hline NNRTI+PI & $38(5.2 \%)$ \\
\hline Without HAART * & $28(3.9 \%)$ \\
\hline \multicolumn{2}{|l|}{ Immunologic state at cohort admission [n (\%)] } \\
\hline $\mathrm{s}_{1}: \mathrm{CD} 4 \geq 500 \mathrm{cell} \mathrm{s} / \mathrm{mm}^{3}$ & $294(40.7 \%)$ \\
\hline $\mathrm{s}_{2}: 350 \leq \mathrm{CD} 4<500$ cells $/ \mathrm{mm}^{3}$ & $170(23.5 \%)$ \\
\hline $\mathrm{s}_{3}: \mathrm{CD} 4<350 \mathrm{cell} / \mathrm{s} / \mathrm{mm}^{3}$ & $258(35.7 \%)$ \\
\hline Previous treatment [n (\%)] & $611(84.6 \%)$ \\
\hline \multicolumn{2}{|l|}{ Cause of death [n] } \\
\hline AIDS-related & 30 \\
\hline Non-AIDS-related & 10 \\
\hline Undetermined & 13 \\
\hline \multicolumn{2}{|l|}{ Number of transitions between states ( $N=3,877$ ) } \\
\hline $\mathrm{s}_{1} \rightarrow \mathrm{s}_{1}$ & 1,712 \\
\hline $\mathrm{s}_{2} \rightarrow \mathrm{s}_{2}$ & 419 \\
\hline $\mathrm{s}_{3} \rightarrow \mathrm{s}_{3}$ & 884 \\
\hline $\mathrm{s}_{1} \rightarrow \mathrm{s}_{2}$ & 178 \\
\hline $\mathrm{s}_{1} \rightarrow \mathrm{s}_{3}$ & 41 \\
\hline $\mathrm{s}_{2} \rightarrow \mathrm{s}_{1}$ & 265 \\
\hline $\mathrm{s}_{2} \rightarrow \mathrm{s}_{3}$ & 140 \\
\hline$s_{3} \rightarrow s_{1}$ & 53 \\
\hline $\mathrm{s}_{3} \rightarrow \mathrm{s}_{2}$ & 185 \\
\hline
\end{tabular}

IDU: injection drug use; IR: interquartile range (quartile 1-quartile 3); NNRTI: non-nucleoside reverse transcriptase inhibitor; PI: protease inhibitor.

* Periods during which the patients did not receive HAART due to adverse effects or due to the patient's or physician's choice. 
state transitions. Ninety-seven per cent of the patients presented disease duration of over 12 months at beginning of the study and $40.7 \%$ of individuals had a "good" immune status (CD4 $\geq$ 500cells $/ \mathrm{mm}^{3}$ ).

The frequency of transition was lowest in patients with extremely long disease durations (Figures 1a, 1b, 1c, and 1d). The $\mathrm{s}_{2} \rightarrow \mathrm{s}_{1}$ and $\mathrm{s}_{2} \rightarrow \mathrm{s}_{3}$ transitions showed small deviations from zero, whereas logarithm HR ( $\log \mathrm{HR})$ was significantly different from zero for the $s_{1} \rightarrow s_{2}$ and $s_{3} \rightarrow s_{2}$ transitions. With regard to the $s_{1} \rightarrow s_{2}$ transition, patients with disease duration under 48 months had a greater risk of disease progression, whereas those with disease duration between 48 and 72 months had a lower risk. With regard to the $\mathrm{s}_{3} \rightarrow \mathrm{s}_{2}$ transition, patients with disease durations between 12 and 72 months presented higher $\log \mathrm{HR}$, while those with durations of over 72 months presented lower $\log \mathrm{HR}$. A disease duration of over 200 months appeared to influence the $\log \mathrm{HR}$ values for the $\mathrm{s}_{1} \rightarrow \mathrm{s}_{2}$ and $\mathrm{s}_{2} \rightarrow \mathrm{s}_{1}$ transitions; however, the limited number of individuals with such long duration periods reduced the reliability of this finding.

The smallest number of transitions was noted for patients with a low adherence rate (Figures 1e, If, $1 \mathrm{~g}$, and $1 \mathrm{~h})$. A significantly different from zero $\log \mathrm{HR}$ value was found for all transitions apart from $\mathrm{s}_{2} \rightarrow \mathrm{s}_{1}$; all other transitions were similar in shape. Patients with an adherence rate below $60 \%$ were more likely to move from $s_{1}$ to $s_{2}$ and from $s_{2}$ to $s_{3}$. The association between an adherence rate below $60 \%$ and a transition from $\mathrm{s}_{3}$ to $\mathrm{s}_{2}$ was negative. A decreasing risk of transition between all stages was observed for patients with adherence rates between $40 \%$ and $60 \%$, with the exception of the $s_{2} \rightarrow s_{1}$ transition which was not associated with adherence. The cut-off points for the adherence variable were therefore set at $40 \%$ and $60 \%$.

Table 2 shows the crude HR values obtained using the simple multi-state models for each of the eight covariates, of which only education, disease duration, regimen and adherence had significant associations with different transitions. Patients with a higher level of education were more likely to move from a more severe state $\left(s_{3}\right)$ to the intermediate state $\left(s_{2}\right)$. Patients with disease durations between two and four years were more likely to experience a transition between $s_{1}$ and $s_{2}$ and were more likely to move from $s_{3}$ to $s_{2}$ than those with disease durations of over six years. Patients who received NNRTI therapy without PI were more likely to move between $s_{3}$ to $s_{2}$. Patients with lower adherence rates $(<40 \%)$ were more likely to experience a transition between $s_{1}$ and $s_{2}$ to $s_{3}$ than those with higher adherence rates (> 60\%), and patients with adherence rates between $40 \%$ and $60 \%$ were more likely to experience a transition between $s_{2}$ and $s_{3}$ than those with higher adherence rates.

With regard to the likelihood-ratio test, when the eight variables were included in the multiple model, only four variables were significant at the $5 \%$ level: duration of disease, regimen, prior treatment and adherence (Table 3).

Table 4 shows the results of the final multiple model, including the probability of misclassifications estimate. Compared to the model that does not include misclassifications (Table 3), this model showed greater effects in the same direction, except for certain transitions, which were insignificant. Each one-year increase in age led to a reduction in the hazard ratio $\left(\mathrm{s}_{2} \rightarrow \mathrm{s}_{1}\right)$ of $3 \%$ (HR $=0.97)$. Patients with disease durations between two and four years were 2.41 times more likely to move from $s_{3}$ to $s_{2}$ than those with disease durations of over six years. Patients with an adherence rate below $40 \%$ were more likely to move from $s_{1}$ to $s_{2}$, and patients with an adherence rate between 40 and $60 \%$ were 4.47 times more likely to move from $s_{2}$ to $s_{3}$. In contrast to the model that does not include misclassification, the hazard ratio of a transition from $\mathrm{s}_{2}$ to $\mathrm{s}_{3}$ in patients receiving NNRTI therapy without PI was insignificant (Table 3).

The misclassification model indicated that only $68.6 \%$ of patients in the $s_{2}$ state were correctly classified; $17.9 \%$ of those that should have been included in the $s_{2}$ state were classified as $\mathrm{s}_{1}$, and $13.5 \%$ were classified as $\mathrm{s}_{3}$. A total of $5.8 \%$ of patients in the most severe immune-deficient state $\left(s_{3}\right)$ were misclassified and should have been in the $s_{2}$ state. In contrast, $96.8 \%$ of patients in the $\mathrm{s}_{1}$ state were correctly classified.

\section{Discussion}

The use of the multi-state model, as opposed to the traditional Cox regression, improved substantially the understanding of variation in risk factors related to the evolution of this chronic disease. Foucher et al. 23 used multi-state models to estimate transitions between states based on VL and CD4 counts. They found that gender, age, co-infection with hepatitis $\mathrm{B}$, co-infection with hepatitis $\mathrm{C}$ and exposure category were predictors of the intensity of transitions between different states. These same factors were not found by our study, since the variables hepatitis B and C were not included in the model.

The most significant difference between studies that use multi-state models is the defini- 
Figure 1

Splines of log-hazard ratio (HR) for duration of disease and proportion of adherence in patients diagnosed with AIDS receiving highly active anti-retroviral therapy (HAART). Instituto de Pesquisa Clínica Evandro Chagas, Fundação Oswaldo Cruz (IPEC/Fiocruz), Rio de Janeiro, Brazil, 2006-2008.

1a) Disease duration (transition $s_{1} \rightarrow s_{2}$ )

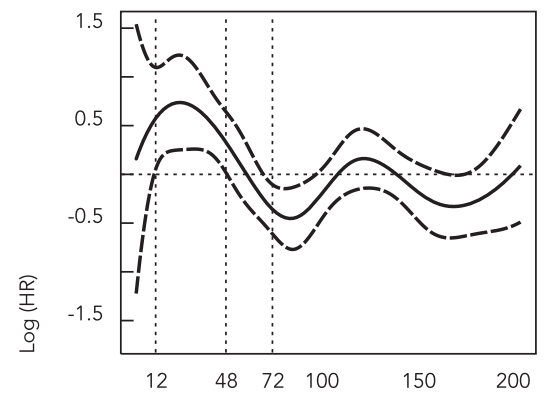

1c) Disease duration (transition $s_{2} \rightarrow s_{3}$ )

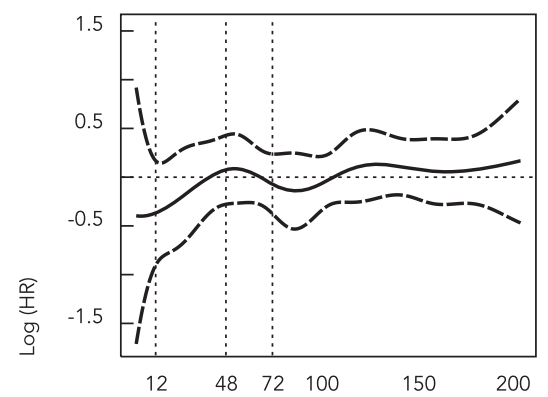

1e) Adherence (transition $s_{1} \rightarrow s_{2}$ )

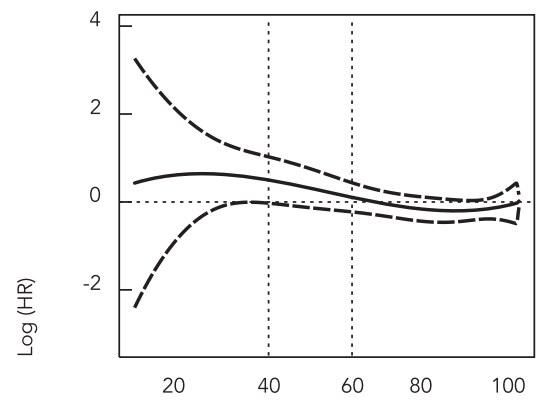

Time since 1st HIV + (months)

Time since 1 st HIV + (months) 1b) Disease duration (transition $\mathrm{s}_{2} \rightarrow \mathrm{s}_{1}$ )

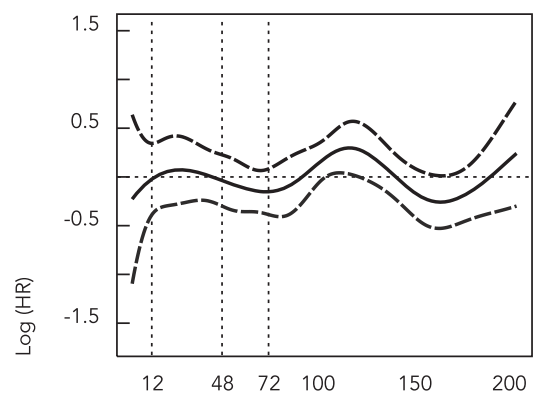

Time since 1 st HIV + (months)

1d) Disease duration (transition $s_{3} \rightarrow s_{2}$ )

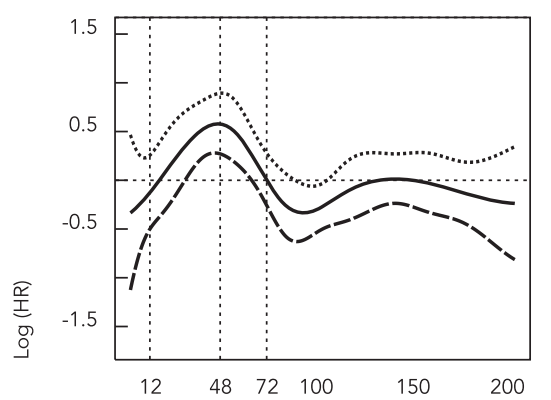

Time since 1 st $\mathrm{HIV}+$ (months)

1f) Adherence (transition $s_{2} \rightarrow s_{1}$ )

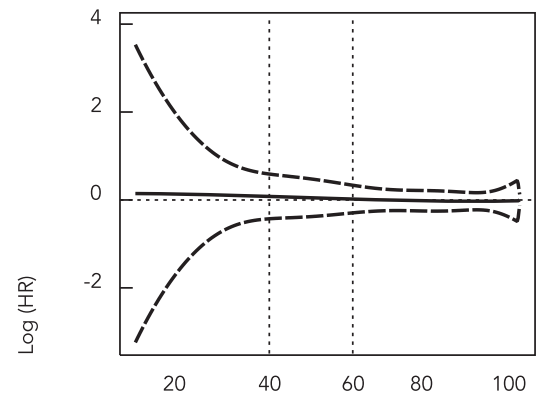

Adherence (\%)

(continues) 
1g) Adherence (transition $s_{2} \rightarrow s_{3}$ )

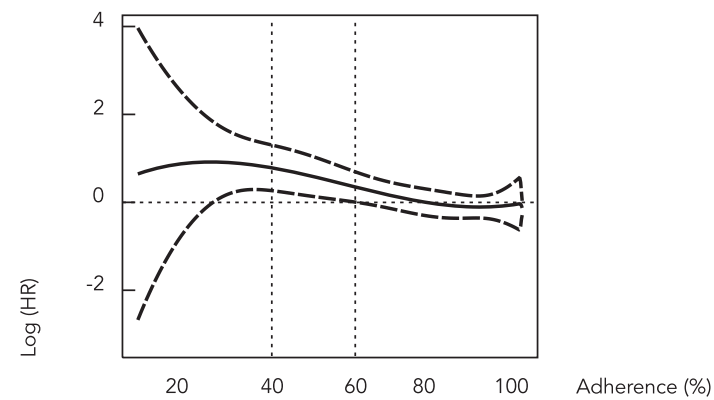

1h) Adherence (transition $s_{3} \rightarrow s_{2}$ )

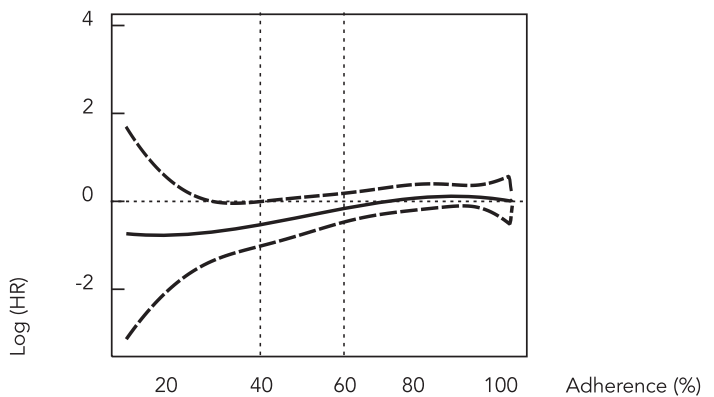

Table 2

Simple multi-state model for patients diagnosed with AIDS and receiving highly active anti-retroviral therapy (HAART). Instituto de Pesquisa Clínica Evandro Chagas, Fundação Oswaldo Cruz (IPEC/Fiocruz), Rio de Janeiro, Brazil.

\begin{tabular}{|c|c|c|c|c|}
\hline \multirow[t]{2}{*}{ Variables/Categories } & \multicolumn{4}{|c|}{ Crude hazard ratio $(95 \% \mathrm{Cl})$} \\
\hline & $\mathrm{s}_{1} \rightarrow \mathrm{s}_{2}$ & $s_{2} \rightarrow s_{1}$ & $s_{2} \rightarrow s_{3}$ & $\mathrm{~s}_{3} \rightarrow \mathrm{s}_{2}$ \\
\hline \multicolumn{5}{|l|}{ Sex } \\
\hline Male vs. female * & $1.35(0.99-1.82)$ & $1.11(0.86-1.43)$ & $1.21(0.86-1.69)$ & $1.02(0.76-1.35)$ \\
\hline Age (years) & $1.00(0.98-1.00)$ & $0.99(0.99-1.03)$ & $1.01(0.99-1.03)$ & $1.01(0.99-1.02)$ \\
\hline \multicolumn{5}{|l|}{ Functional literacy } \\
\hline 4 years or more of schooling vs. less than 4 years of schooling * & $0.74(0.53-1.03)$ & $0.85(0.64-1.14)$ & $1.40(0.94-2.09)$ & $1.40(1.01-1.96)$ \\
\hline \multicolumn{5}{|l|}{ Exposure to HIV } \\
\hline Non sexual vs. sexual * & $1.01(0.53-1.92)$ & $1.22(0.75-1.99)$ & $1.65(0.89-3.06)$ & $1.24(0.72-2.12)$ \\
\hline \multicolumn{5}{|l|}{ Time since $1 \mathrm{st} \mathrm{HIV+}$} \\
\hline$\leq 12$ months vs. $>72$ months * & $1.40(0.55-3.56)$ & $1.05(0.59-1.90)$ & $0.58(0.21-1.61)$ & $0.90(0.50-1.63)$ \\
\hline $13-48$ months vs. $>72$ months * & $1.98(1.32-2.98)$ & $0.91(0.65-1.28)$ & $0.78(0.50-1.23)$ & $1.51(1.05-2.17)$ \\
\hline 49-72 months vs. $>72$ months * & $0.99(0.67-1.45)$ & $0.86(0.62-1.19)$ & $1.02(0.66-1.56)$ & $1.74(1.18-2.56)$ \\
\hline \multicolumn{5}{|l|}{ HAART } \\
\hline NNRTI+PI or PI vs. without HAART * & $0.82(0.53-1.25)$ & $0.82(0.55-1.21)$ & $1.01(0.61-1.68)$ & $1.04(0.64-1.69)$ \\
\hline NNRTI vs. without HAART * & $0.78(0.51-1.22)$ & $0.73(0.49-1.10)$ & $0.87(0.51-1.48)$ & $2.19(1.32-3.61)$ \\
\hline \multicolumn{5}{|l|}{ Previous treatment } \\
\hline No vs. yes * & $0.79(0.54-1.17)$ & $0.54(0.54-1.08)$ & $1.33(0.81-2.17)$ & $1.26(0.84-1.90)$ \\
\hline \multicolumn{5}{|l|}{ Adherence } \\
\hline$\leq 40 \%$ vs. $>60 \%$ * & $2.94(1.16-7.39)$ & $2.19(0.79-6.09)$ & $3.09(1.37-7.00)$ & $0.45(0.20-1.01)$ \\
\hline Between $40 \%$ and $60 \%$ vs. $>60 \%$ * & $1.05(0.57-1.93)$ & $0.76(0.42-1.36)$ & $2.06(1.19-3.57)$ & $0.72(0.42-1.23)$ \\
\hline
\end{tabular}

NNRTI: non-nucleoside reverse transcriptase inhibitor; PI: protease inhibitor; $\mathrm{s}_{1}$ : CD4 $\geq 500$ cells/mm3; $\mathrm{s}_{2}$ : $350 \leq \mathrm{CD} 4<500$ cells/mm3; $\mathrm{s}_{3}$ : CD4 < 350cells/mm3; 95\% Cl: 95\% confidence interval.

* Reference category.

Note: without HAART = periods during which the patients did not receive HAART due to adverse effects or due to the patient's or physician's choice. 
Multiple multi-state model in patients diagnosed with AIDS and receiving highly active anti-retroviral therapy (HAART). Instituto de Pesquisa Clínica Evandro Chagas, Fundação Oswaldo Cruz (IPEC/Fiocruz), Rio de Janeiro, Brazil.

\begin{tabular}{|c|c|c|c|c|}
\hline \multirow[t]{2}{*}{ Variables/Categories } & \multicolumn{4}{|c|}{ Adjusted hazard ratio $(95 \% \mathrm{Cl})$} \\
\hline & $s_{1} \rightarrow s_{2}$ & $s_{2} \rightarrow s_{1}$ & $s_{2} \rightarrow s_{3}$ & $s_{3} \rightarrow s_{2}$ \\
\hline \multicolumn{5}{|l|}{ Sex } \\
\hline Male vs. female * & $1.40(1.03-1.90)$ & $1.23(0.94-1.60)$ & $1.30(0.91-1.86)$ & $0.96(0.71-1.30)$ \\
\hline Age (years) & $1.00(0.98-1.02)$ & $0.99(0.97-1.00)$ & $1.01(0.99-1.03)$ & $1.01(0.99-1.03)$ \\
\hline \multicolumn{5}{|l|}{ Functional literacy } \\
\hline 4 years or more of schooling vs. less than 4 years of schooling * & $0.75(0.53-1.06)$ & $0.78(0.57-1.07)$ & $1.29(0.84-1.98)$ & $1.41(0.99-2.00)$ \\
\hline \multicolumn{5}{|l|}{ Exposure to HIV } \\
\hline Non sexual vs. sexual * & $1.21(0.61-2.41)$ & $1.49(0.87-2.54)$ & $1.53(0.78-3.01)$ & $1.04(0.59-1.84)$ \\
\hline \multicolumn{5}{|l|}{ Time since 1st HIV+ } \\
\hline$\leq 12$ months vs. $>72$ months * & $1.50(0.57-3.91)$ & $0.91(0.48-1.72)$ & $0.63(0.21-1.83)$ & $0.74(0.40-1.37)$ \\
\hline $13-48$ months vs. $>72$ months * & $2.10(1.34-3.29)$ & $0.91(0.63-1.30)$ & $0.81(0.50-1.33)$ & $1.30(0.86-1.96)$ \\
\hline 49-72 months vs. $>72$ months * & $1.03(0.68-1.56)$ & $0.86(0.60-1.23)$ & $1.17(0.72-1.90)$ & $1.80(1.19-2.72)$ \\
\hline \multicolumn{5}{|l|}{ HAART } \\
\hline NNRTI+PI or PI vs. without HAART * & $0.81(0.53-1.25)$ & $0.79(0.53-1.18)$ & $0.96(0.57-1.61)$ & $0.99(0.60-1.63)$ \\
\hline NNRTI vs. without HAART * & $0.74(0.47-1.16)$ & $0.72(0.47-1.09)$ & $0.83(0.47-1.45)$ & $2.02(1.19-3.41)$ \\
\hline \multicolumn{5}{|l|}{ Previous treatment } \\
\hline No vs. yes * & $0.70(0.47-1.06)$ & $0.76(0.53-1.09)$ & $1.46(0.87-2.44)$ & $1.01(0.65-1.56)$ \\
\hline \multicolumn{5}{|l|}{ Adherence } \\
\hline$\leq 40 \%$ vs. $>60 \%$ * & $2.84(0.99-8.09)$ & $2.36(0.82-6.79)$ & $2.86(1.25-6.58)$ & $0.51(0.23-1.14)$ \\
\hline Between $40 \%$ and $60 \%$ vs. $>60 \%$ * & $0.95(0.51-1.77)$ & $0.72(0.40-1.28)$ & $2.01(1.14-3.55)$ & $0.71(0.42-1.22)$ \\
\hline \multicolumn{5}{|c|}{ 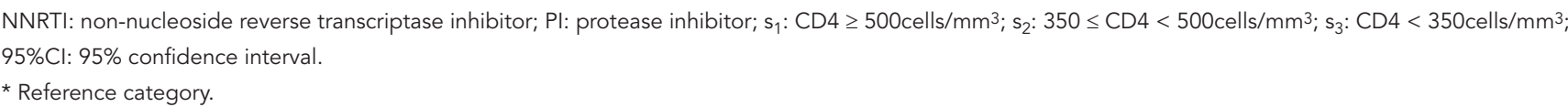 } \\
\hline
\end{tabular}

tion of the different states. Although CD4 count, VL and the incidence of opportunistic infections are used to assess AIDS progression from a clinical point of view, few studies have used these multiple variables. The high cost of the VL assays is a major obstacle to the adoption of this test, therefore restricting its availability compared to CD4 cell counts test. Foucher et al. 23 used both tests simultaneously and considered all of the possible combinations of two VL groups (cutoff at 400 copies $/ \mathrm{mL}$ ) and two CD4 (cut-off at 200cells $/ \mathrm{mm}^{3}$ ).

None of the studies that used multi-state approaches to model AIDS progression investigated patient adherence 22,23,24. The HR observed in our study was found to be higher than the one observed by Gross et al. 4 but lower than that found by a previous study with the same cohort 5. However, both studies investigated therapeutic failure using Cox regression models with just one end-point. Regarding thresholds for determining levels of adherence, we found lower cut-off points ( $40 \%$ and $60 \%$ of adherence) than other studies ( $80 \%$ to $95 \%$ of adherence) $4,5,34,35,36$, possibly due to the use of CD4 cell count instead of VL or mortality. It is important to note that there is no consensus regarding the most appropriate method to measure adherence 37 or the threshold that should be adopted to define non adherence ${ }^{3}$. It is recommended that an empirical inspection of the shape of the curve, as carried out by this study using splines, should be applied to other studies and contexts in order to define an adequate cut-off point.

Another covariate used by the study by Campos 5 was the daily average number of pills taken as a proxy of difficulty of adherence to the therapy. We considered the medicines with potential side effects 1 , which, in our understanding, is more relevant.

Previous duration of the disease before beginning the study was a relevant factor in the transition to the intermediate state. As expected, resistance to anti-retroviral drugs emerges as disease 
Final multiple multi-state model, with estimation of misclassification error, in patients diagnosed with AIDS receiving highly active anti-retroviral therapy (HAART). Instituto de Pesquisa Clínica Evandro Chagas, Fundação Oswaldo Cruz (IPEC/Fiocruz), Rio de Janeiro, Brazil.

\begin{tabular}{|c|c|c|c|c|}
\hline \multirow[t]{2}{*}{ Variables/Categories } & \multicolumn{4}{|c|}{ Adjusted hazard ratio $(95 \% \mathrm{Cl})$} \\
\hline & $s_{1} \rightarrow s_{2}$ & $s_{2} \rightarrow s_{1}$ & $s_{2} \rightarrow s_{3}$ & $s_{3} \rightarrow s_{2}$ \\
\hline \multicolumn{5}{|l|}{ Sex } \\
\hline Male vs. female * & $1.13(0.46-2.75)$ & $0.82(0.51-1.32)$ & $1.85(0.47-7.28)$ & $0.57(0.29-1.10)$ \\
\hline Age (years) & $0.98(0.93-1.02)$ & $0.97(0.95-0.99)$ & $1.02(0.96-1.09)$ & $1.01(0.98-1.05)$ \\
\hline \multicolumn{5}{|l|}{ Functional literacy } \\
\hline 4 years or more of schooling vs. less than 4 years of schooling * & $0.52(0.19-1.37)$ & $0.70(0.41-1.21)$ & $0.51(0.14-1.83)$ & $1.17(0.55-2.49)$ \\
\hline \multicolumn{5}{|l|}{ Exposure to HIV } \\
\hline Non sexual vs. sexual * & $0.53(0.00-114.77)$ & $1.73(0.65-4.60)$ & $2.29(0.27-19.52)$ & $1.01(0.28-3.65)$ \\
\hline \multicolumn{5}{|l|}{ Time since 1st HIV+ } \\
\hline$\leq 12$ months vs. $>72$ months * & $0.56(0.01-55.53)$ & $1.27(0.52-3.10)$ & $1.15(0.10-13.27)$ & $2.13(0.81-5.59)$ \\
\hline 13-48 months vs. $>72$ months * & $1.30(0.39-4.35)$ & $0.73(0.39-1.36)$ & $2.21(0.54-9.14)$ & $3.41(1.47-7.92)$ \\
\hline 49-72 months vs. $>72$ months * & $0.99(0.34-2.89)$ & $0.90(0.46-1.75)$ & $1.16(0.20-6.79)$ & $1.71(0.53-5.48)$ \\
\hline \multicolumn{5}{|l|}{ HAART } \\
\hline NNRTI+PI or PI vs. without HAART * & $1.18(0.30-4.62)$ & $1.17(0.46-2.94)$ & $1.67(0.22-12.94)$ & $1.25(0.35-4.50)$ \\
\hline NNRTI vs. without HAART * & $0.70(0.16-3.15)$ & $0.88(0.32-2.38)$ & $0.63(0.09-4.62)$ & $2.41(0.61-9.53)$ \\
\hline \multicolumn{5}{|l|}{ Previous treatment } \\
\hline No vs. yes * & $2.49(0.43-14-47)$ & $1.35(0.69-2.63)$ & $6.73(0.69-65.76)$ & $1.20(0.39-3.71)$ \\
\hline \multicolumn{5}{|l|}{ Adherence } \\
\hline$\leq 40 \%$ vs. $>60 \%$ * & $4.84(1.06-22.11)$ & $1.56(0.40-6.11)$ & $5.33(0.88-32.48)$ & $0.08(0.001-5.33)$ \\
\hline Between $40 \%$ and $60 \%$ vs. $>60 \%$ * & $0.41(0.01-16.97)$ & $0.72(0.23-2.31)$ & $5.47(1.27-23.50)$ & $0.59(0.17-2.00)$ \\
\hline $\begin{array}{l}\text { Misclassification error: } s_{\text {true }} \text { state } \rightarrow \mathrm{s}_{\text {observed state }} \\
\text { (probability of observed state given true state) }\end{array}$ & 0.032 & 0.179 & 0.135 & 0.058 \\
\hline \multicolumn{5}{|c|}{$\begin{array}{l}\text { NNRTI: non-nucleoside reverse transcriptase inhibitor; Pl: protease inhibitor; } \mathrm{s}_{1}: \mathrm{CD} 4 \geq 500 \text { cells } / \mathrm{mm}^{3} ; \mathrm{s}_{2}: 350 \leq \mathrm{CD} 4<500 \mathrm{cells} / \mathrm{mm}^{3} ; \mathrm{s}_{3}: \mathrm{CD}_{4}<350 \mathrm{cells} / \mathrm{mm}^{3} \\
95 \% \mathrm{Cl}: 95 \% \text { confidence interval. }\end{array}$} \\
\hline
\end{tabular}

duration increases which hinders the patient's capacity to maintain satisfactory CD4 counts and VLs, and opens the way for the development of opportunistic diseases 1 .

Models that include misclassification were used due to the limitations of the use of CD4 counts as the only method to classify disease progression. As expected, errors in the middle range states were more frequent than in the extreme states. The most significant error in the intermediate state may be related to the small CD4 count range (between 350 and 500cells $/ \mathrm{mm}^{3}$ ) and the possibility of two classification errors due to two adjacent states. The World Health Organization (WHO) 14 has emphasised that few studies have provided these estimates and has also reported that greater concentrations of values near cutoff points are typically associated with a larger number of misclassifications.
When estimating survival in patients with chronic diseases, such as AIDS, that involve the transition between different states, it is fundamentally important to consider progression between the different degrees of chronicity. AIDS multi-state modeling is capable of identifying the factors associated with each transition between the degrees of chronicity defined by CD4 count ranges. Nevertheless, the level of misclassification indicates that caution should be taken when using CD4 counts as the sole measurement of the degree of chronicity. The identification of factors, such as therapy adherence, disease duration and age, associated with the current state of the patient, is an important contribution to guide clinical interventions and extend healthy life. 


\section{Resumen}

Existen pocos estudios sobre el SIDA que evalúan factores asociados al fallo terapéutico, consideran su evolución lenta, con el pasaje por múltiples estados de salud, consecuencia del uso de antirretrovirales. En ese artículo se estudiaron factores asociados a la progresión entre estados inmunes, enfocando adhesión, en 722 pacientes VIH+ acompañados durante 3 años. El desenlace fue el cómputo de células CD4, clasificado en $s_{1}(C D 4 \geq 500)$, $s_{2}(350 \leq C D 4<500)$ y $s_{3}(C D 4<350)$. Las transiciones entre estados se modelaron por modelos multi-estado. La adhesión a la terapia antirretroviral y el tiempo de enfermedad están asociados diferentemente al cambio del estado inmune vivido por el paciente. Baja adhesión a la terapia aumentó el riesgo de $s_{1} \rightarrow s_{2}$ y una adhesión intermedia aumentó de un $s_{2} \rightarrow s_{3}$. Por otro lado, edades elevadas y tiempo de enfermedad de 2 a 4 años se presentan como factores de protección en la progresión del SIDA. El modelo multi-estado es un enfoque poderoso en el estudio de enfermedades crónicas, por estimar los factores asociados a cada etapa de la evolución de enfermedades crónicas, posibilitando la adopción de intervenciones más individualizadas y eficaces.

VIH; Progresión de la Enfermedad; Cooperación del Paciente; Análisis de Supervivencia

\section{Contributors}

R. V. C. Oliveira, S. E. Shimakura and M. S. Carvalho were responsible for study design, conducted statistical analysis, and drafted this article. D. P. Campos critically revised data, suggested new approaches for data analysis and approved the final version of this manuscript. V. G. Veloso and B. Grinsztejn critically revised data and approved the final version of this article. F. P. Victoriano assisted in database handling, participated in the conception of important variables and approved the final version of this article. S. R. Ribeiro participated in data collection, gave clinical support for the creation of variables and revised the final version of this article.

\section{Acknowledgments}

The authors would like to thank the professionals involved in caring for the HIV+ patients and the staff of the Statistics and Documentation Service for maintaining the database. The authors would also like to thank FAPERJ and FIOTEC for their financial support.

\section{Conflict of interest}

None declared.

\section{References}

1. Ministério da Saúde. Recomendações para terapia anti-retroviral em adultos infectados pelo HIV 2008. Brasília: Ministério da Saúde; 2008.

2. World Health Organization. The global burden of disease: 2004 update. Geneva: Word Health Organization; 2008.

3. Stone VE. Optimizing the care of minority patients with HIV/AIDS. Clin Infect Dis 2004; 38:400-4.

4. Gross R, Yip B, Lo Re 3rd V, Wood E, Alexander CS Harrigan PR, et al. A simple, dynamic measure of antiretroviral therapy adherence predicts failure to maintain HIV-1 suppression. J Infect Dis 2006; 194:1108-14.

5. Campos DP. Impacto dos esquemas de anti-retrovirais nas condições clínicas e na sobrevida dos pacientes com diagnóstico de AIDS [Dissertação de Mestrado]. Rio de Janeiro: Escola Nacional de Saúde Pública Sergio Arouca, Fundação Oswaldo Cruz; 2009
6. Lavolé A, Chouaïd C, Baudrin L, Wislez M, Raguin G, Pialoux G, et al. Effect of highly active antiretroviral therapy on survival of HIV infected patients with non-small-cell lung cancer. Lung Cancer 2009; 65:345-50.

7. Ragni MV, Nalesnik MA, Schillo R, Danq Q. Highly active antiretroviral therapy improves ESLD-free survival in HIV-HCV co-infection. Haemophilia 2009; 15:552-8.

8. Zacarelli M, Lorenzini P, Tozzi V, Forbici F, Ceccerini-Silberstein F, Gori C, et al. Effect of suppressing HIV viremia on the HIV progression of patients undergoing a genotype resistance test after treatment failure. Infection 2009; 37:203-9.

9. Chu KM, Mahlangeni G, Swannet S, Ford NP, Boulle A, Van Cutsem G. AIDS-associated Kaposi's sarcoma is linked to advanced disease and high mortality in a primary care HIV programme in South Africa. J Int AIDS Soc 2010; 13:23. 
10. Keiser O, Tweya H, Braitstein P, Dabis F, MacPhail P, Boulle A, et al. Mortality after failure of antiretroviral therapy in sub-Saharan Africa. Trop Med Int Health 2010; 15:251-8.

11. Koethe JR, Limbada MI, Giganti MJ, Nyirenda CK, Mulenga L, Wester CW, et al. Early immunologic response and subsequent survival among malnourished adults receiving antiretroviral therapy in Urban Zambia. AIDS 2010; 24:2117-21.

12. Neuhaus J, Angus B, Kowalska JD, La Rosa A, Sampson J, Wentworth D, et al. Risk of all-cause mortality associated with nonfatal AIDS and serious non-AIDS events among adults infected with HIV. AIDS 2010; 24:697-706.

13. Ministério da Saúde. Recomendações para terapia anti-retroviral em adultos infectados pelo HIV 2008. Suplemento II: critérios para início do tratamento antiretroviral. Brasília: Ministério da Saúde; 2010.

14. World Health Organization. Technical brief on CD4 technologies. 2010 ART guidelines for adults and adolescents. Geneva: World Health Organization; 2010.

15. Shih HC, Chou P, Liu CM, Tung TH. Estimation of progression of multi-state chronic disease using the Markov model and prevalence pool concept. BMC Med Inform Decis Mak 2007; 7:34.

16. Pan SL, Wu HM, Yen AM, Chen TH. A Markov regression random-effects model for remission of functional disability in patients following a first stroke: a Bayesian approach. Stat Med 2007; 26:5335-53.

17. Gil J, Alioum A, Ketzoian C, Desport JC, DruetCabanac M, Couratier P. Disease progression and survival in ALS: first multi-state model approach. Amyotroph Lateral Scler 2007; 8:224-9.

18. Mathieu E, Loup P, Dellamonica P, Daurès JP. Markov modelling of immunological and virological states in HIV-1 infected patients. Biom J 2005; 47:834-46.

19. Klein JP, Shu Y. Multi-state models for bone marrow transplantation studies. Stat Methods Med Res 2002; 11:117-39.

20. Bonneterre J, Bercez C, Bonneterre ME, Lenne X, Dervaux B. Cost-effectiveness analysis of breast cancer adjuvant treatment: FEC 50 versus FEC 100 (FASG05 study). Ann Oncol 2005; 16:915-22.

21. Meira-Machado L, Cadarso-Suárez C, Uña-Álvarez J. An R library for the analysis of multi-state survival data. Computer Methods and Programs in Biomedicine 2007; 86:131-40.

22. Kousignian I, Abgrall S, Duval X, Descamps D, Matheron S, Costagliola D, et al. Modeling the time course of CD4 T-lymphocyte counts according to the level of virologic rebound in HIV-1-infected patients on highly active antiretroviral therapy. J Acquir Immune Defic Syndr 2003; 34:50-7.

23. Foucher Y, Mathieu E, Saint-Pierre P, Durand JP, Daurès JP. A semi-Markov model based on generalized Weibull distribution with an illustration for HIV disease. Biom J 2005; 47:825-33.
24. Mathieu E, Foucher Y, Dellamonica P, Daurès JP. Parametric and non homogeneous semi-Markov process for HIV control. Methodol Comput Appl Probab 2007; 9:389-97.

25. Campos DP, Lisboa CSV, Matzenbacher L, Grinsztejn B, Veloso VG, Ribeiro SR, et al. Banco de dados de indivíduos HIV-positivos para fins de pesquisa clínica: elaboração e atualização. http://www. sbis.org.br/cbis/arquivos/724.pdf (accessed on 18/Jan/2012).

26. United Nations Educational, Scientific and Cultural Organization. Education for all: literacy for life. Paris: United Nations Educational, Scientific and Cultural Organization; 2005.

27. Ministério da Saúde. Referência rápida de dispensação de medicamentos ARV pelo SICLOM - Sistema de Controle Logístico de Medicamentos. Brasília: Ministério da Saúde; 2007.

28. Hougaard P. Multi-state models: a review. Lifetime Data Anal 1999; 5:239-64.

29. Andersen PK. Competing risks as a multi-state model. Stat Methods Med Res 2002; 11:203-15.

30. Huzurbazar AV. Flowgraph models for multistate time-to-event data. New Jersey: John Wiley \& Sons; 2005. (Wiley Series in Probability and Statistics).

31. Titman AC, Sharples LD. Model diagnostics in multi-state models. Stat Methods Med Res 2009; 19:621-51.

32. Beerenwinkel N, Drton M. A mutagenetic tree hidden Markov model for longitudinal clonal HIV sequence data. Biostatistics 2007; 8:53-71.

33. Jackson $\mathrm{CH}$. Multi-state models for panel data: the msm package for R. J Stat Soft 2011; 38:1-29.

34. Wood E, Hogg RS, Yip B, Harrigan PR, O'Shaughnessy MV, Montaner JS. Is there a baseline CD4 cell count that precludes a survival response to modern antiretroviral therapy? AIDS 2003; 17:711-20.

35. Wood E, Hogg RS, Yip B, Harrigan PR, O’Shaughnessy MV, Montaner JS. Effect of medication adherence on survival of HIV-infected adults who start highly active antiretroviral therapy when CD4+cell count is 0.200 to $0.350 \times 10$ (9) cells/L Ann Intern Med 2003; 139:810-6.

36. Hogg RS, Heath K, Bangsberg D, Yip B, Press N, O'Shaughnessy MV. Intermittent use of triplecombination therapy is predictive of mortality at baseline and after 1 year of follow-up. AIDS 2002; 16:1175-83.

37. Osteberg L, Blaschke T. Adherence to medication. N Engl J Med 2005; 353:487-97.

Submitted on 22/Jun/2012

Final version resubmitted on $17 /$ Oct/2012

Approved on 06/Dec/2012 